\title{
Concomitant hypo-hyperdontia- a rare case report
}

\author{
Dr.PriyankaNiranjane, Dr.SuchitaTarvade/Daokar, Dr.SadashivDaokar, \\ Dr.PallaviDaigavane, Dr.PushkarPatil, Dr.SonaliShelke, \\ Lecturer, Dept of Orthodontics, SPDC Dental College, Wardha, India \\ Professor \& PG Guide, Dept of Orthodontics, CSMSS Dental College, Aurangabad, India \\ Professor, Dept of Conservative Dentist, CSMSS Dental College, Aurangabad, India \\ Associate Professor, SPDC, Dental College, Wardha, India \\ Consulting Orthodontist, India \\ Consulting Orthodontist, India
}

\begin{abstract}
Concomitant hypo-hyperdontia a term introduced by Camerilli, describes a case where hypodontia (absence of one or more teeth) and hyperdontia (supernumerary teeth) are seen in the same individual. Few cases have been reported in literature,frequently associated with syndromic findings. Here we have reported the findings of $\mathrm{CHH}$, in a 13 year boy suffering from UCLP, which is non syndromic, and hence a very very rare finding.
\end{abstract}

\section{Introduction :-}

Although anomalies of tooth number and form are quite common, but concomitant hypo-hyperdontia are very rare. The term was introduced by Camilleri ${ }^{1}$. The term is used to describe a condition where there is simultaneous presence of hypodontia and hyperdontia in the same individual.

Hypodontia is the term used most commonly in describing the phenomenon of congenitally missing teeth. On the other hand hyperdontia is the term used for presence of supernumerary teeth (the one exceeding the normal dental formula) $)^{2}$.

Found mainly in permanent dentition, than in primary dentition.

The etiology is unknown, disturbances in migration, proliferation and differentiation of the neural crest cells and interaction between the epithelial and mesenchymal cells during the initiation of odontogenesis have been suggested etiological factors. ${ }^{3}$

\section{Case report:-}

13 year boy reported to the department of orthodontics with the chief complaint of mal-aligned teeth. On examination, it was detected that the child suffered from unilateral cleft lip and palate . History revealed that the cleft were operated in his childhood (18 months of age). No family history of cleft were found.

Intraoral examination revealed presence of all permanent teeth on right side of the maxillary arch but on the left side of the maxillary arch which was also the cleft side only permanent central incisor, $1^{\text {st }}$ premolar, $1^{\text {st }}$ and $2^{\text {nd }}$ molar were present, primary canine (63)and $2^{\text {nd }}$ molar (65) were found to be over-retained.

In mandibular arch all the permanent teeth were found to be present.

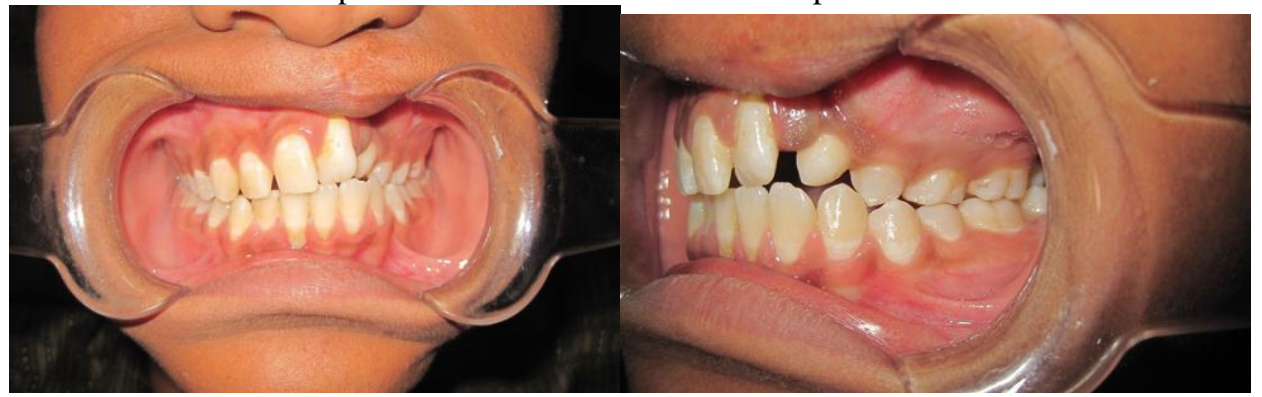

\section{Radiographic investigations:-}

OPG and occlusal radiographs revealed absence of left maxillary $2^{\text {nd }}$ premolar. Where as impacted left permanent canine and a peg shaped supernumerary tooth was found to be present.

3-Dimensional CT scan revealed that there was a shape anomaly with maxillary left central incisor, peg shaped impacted left maxillary left lateral incisor, vertically impacted left maxillary canine and presence of conical supernumerary tooth inverted high into the palate. 


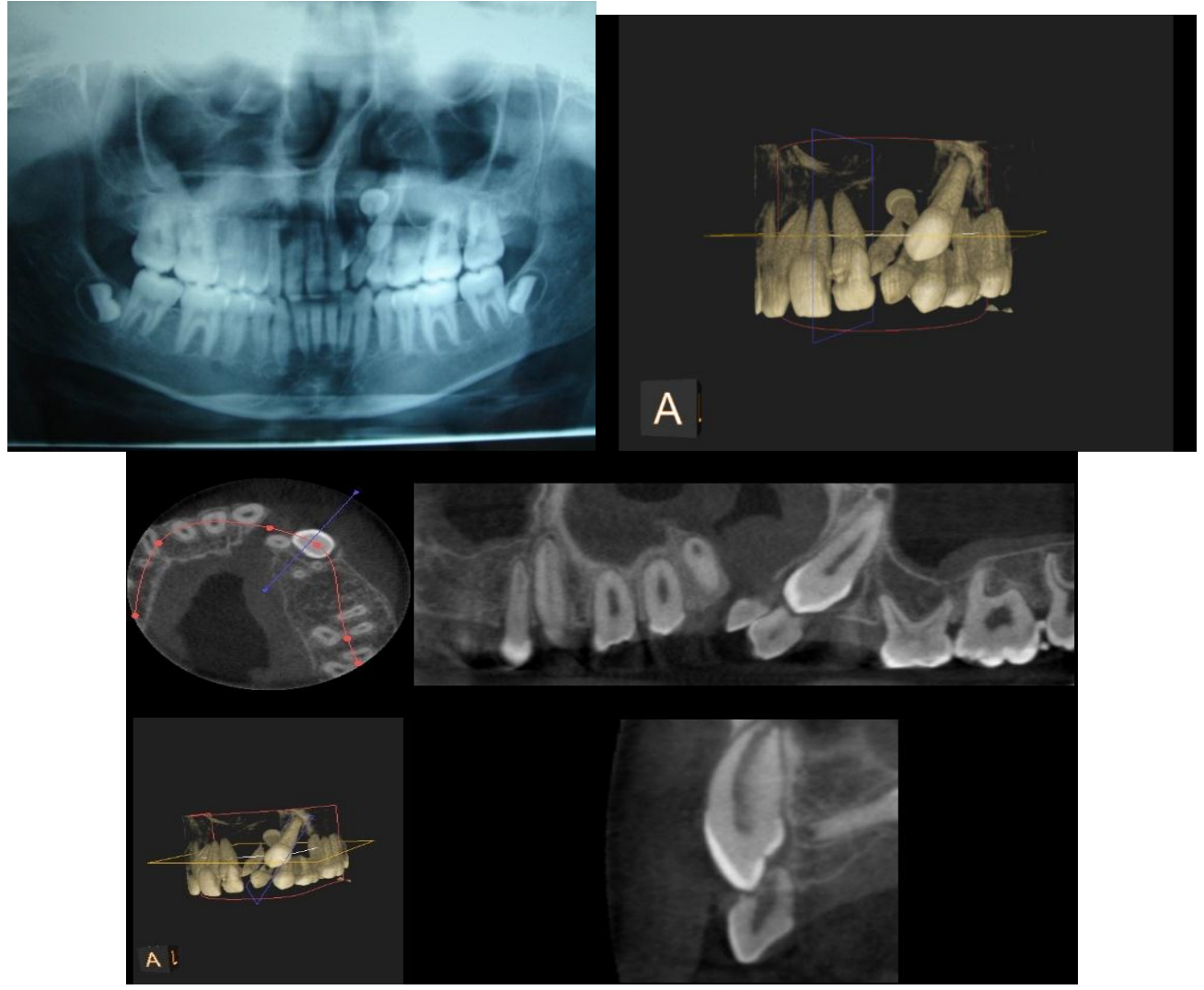

\section{Diagnosis:-}

With above investigations it was diagnosed as a case of concomitant hypo-hyperdontia due to missing left maxillary $2^{\text {nd }}$ premolar(hypodontia) and presence of supernumerary tooth (hyperdontia) in the palatal region with Unilateral Cleft Lip and Palate

\section{Discussion :-}

Concomitant hypo-hyperdontia is a rare phenomenon. The reported prevalence from various studies has beee calculated to range from $0.002 \%$ to $3.1 \%$ (Anthonappa et al , 2008). Hypohyperdontia does not usually manifest in the same arch and very rarely in the same area of an arch as shown by Anthonappa et al, 2008.

Cleft lip and palate cases have shown to bear many anomalies like missing one or many teeth, anomalies of shape of one or many teeth.

Literature reports that the prevalence of missing premolars is higher (18\%) in CLP patients than in general population.

The presence of supernumerary tooth in the cleft region is a rare finding with a prevalence of $0.1-3.8 \%$

To be best of authors knowledge, till date no case of Concomitant hypohyperdontia case associated with non syndromic UCLP have been reported.

Concomitant hypohyperdontia reported in this case associated with non syndromic UCLP is a rare finding and hence should be looked for.Whenever any numeric anomaly of the dentition is noted, a thorough clinical examination followed by judicious use of radiographs is warranted.

Reporting of such rare cases whenever noted is also needed to get a better insight into the pathogenesis and etiological factors contributing to the case, which will further help in prevention, correction and treatment of such cases.

\section{References}

[1]. Camilleri G.E.-Concomitant hypodontia and hyperdontia -a case report, Br. Dent J 1967,123(7), 338-39

[2]. Fernandez- M;o;ntenegro P, Valmaseda-Castellon .E et al - Retrospective study of 145 supernumerary teeth. Med Oral Path Oral Cir Bucal 2006,11,E339-44

[3]. Baccetti.T. - A controlled study of associated dental anomalies.AngleOrthod 1998,68(3), 267-274.

[4]. Kim NY, Baek SH. Cleft sidedness and congenitally missing or malformed permanent maxillary lateral incisors in Korean patients with unilateral cleft lip and alveolus or unilateral cleft lip and palate. Am J OrthodDentofacialOrthop. 2006;130: 752-728,

[5]. Ting-Ting Wu1, Philip K.T.Chen, Lun-Jou Lo, Min-Chi Cheng et al The Characteristics and Distribution of Dental Anomalies in Patients with Cleft. Med J 2011.Vol.34 No. 3 
[6]. Ribeiro LL, Neves LT, Costa B, Gomide MR. Dental anomalies of the permanent lateral incisors and prevalence of hypodontia outside the cleft area in complete unilateral cleft lip and palate. Cleft Palate Craniofac J2003; 40: 172-175,

[7]. Camilleri GE. Concomitant hypodontia and hyperodontia. Case report. Br Dent J 1967; 123(7): 338-39.

[8]. Sharma A. A rare non syndrome case of concomitant multiple supernumerary teeth and partial anodontia. J ClinPediatr Dent 2001;25:167-9.

[9]. Shapira Y, Lubit E, Kuftinec M M Congenitally missing second premolars in cleft lip and cleft palate children. Am J OrthodDentofacialOrthop 1999; 115: 396-400

[10]. Ranta R. Comparison of tooth formation in noncleft and cleft-affected children with and without hypodontia. J Dent Child 1982;49:197-9.

[11]. Anthonappa RP, Lee CK, Yiu CKY, King NM. Hypo-hyperdontia: literature review and report of seven cases. Oral Surg, Oral Med, Oral Pathol, Oral RadiolEndod. 2008; 106:e24-30.

[12]. Munns D: A case of partial anodontia and supernumerary tooth present in the same jaw. Dent Practit Dent Rec. 196;.18:34-37,

[13]. Matsumoto M, Nakagawa Y, Sobue S, Ooshima T. Simultaneous presence of a congenitally missing premolar and supernumerary incisor in the same jaw: Report of case. ASDC J Dent Child. 2001;68:63-6

[14]. Sharma A. A rare case of concomitant hypo-hyperdontia in identical twins. J Indian SocPedodPrev Dent 2008; 26:S79-81.

[15]. Raghavan VH. Mandibular mesiodens with agenesis of central incisors - A rare association. Nigerian Dent J 2009; 17:27-28. 